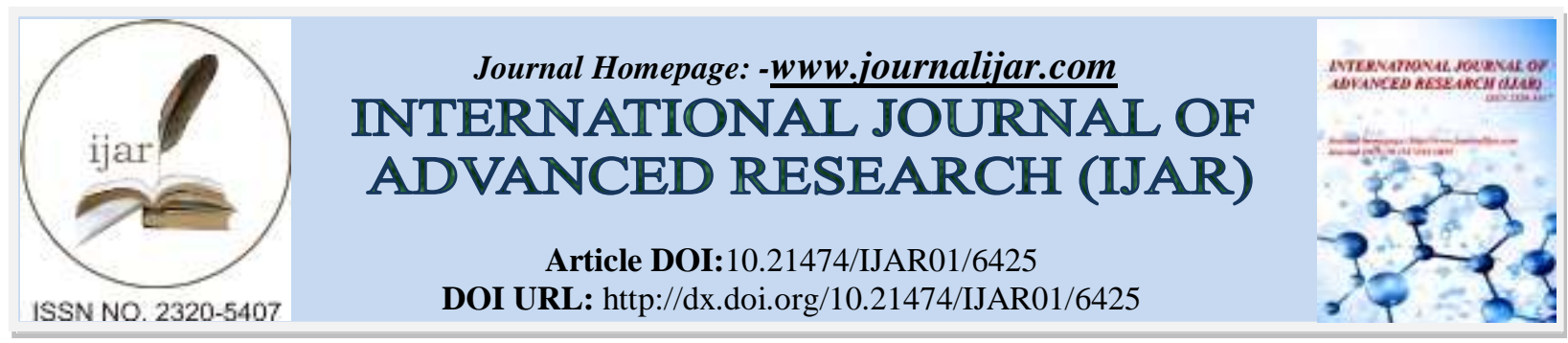

RESEARCH ARTICLE

\title{
SCREENING AND OPTIMIZATION OF NUTRITIONAL CONDITIONS FOR ENHANCED MANNANASE PRODUCTION BY STREPTOMYCES SP. AZA12.
}

*A. S. Zine and S. A.Peshwe.

Government Institute of Science, Aurangabad.

\section{Manuscript Info}

Manuscript History

Received: 03 December 2017

Final Accepted: 05 January 2018

Published: February 2018

Key words:-

Optimization, mannanase activity,

Streptomyces sp.AZA12,

dinitrosalicylic acid, agroresidues.

\begin{abstract}
Different actinomycete isolates were screened for the production of mannanase under submerged state fermentation. Streptomyces $s p$. AZA12 was selected as the most potent isolate with highest enzyme activity and was therefore selected for further studies. The nutritional requirements of Streptomyces $s p$. AZA12 for the production of mannanase in submerged fermentation were investigated. Different agricultural wastes were screened as substitutes to commercial substrate for mannanase production. Soyastraw was found to be the most effective carbon source with highest mannanase activity of 48.33 $\mathrm{U} / \mathrm{ml}$. Aspargine was obtained to be the best nitrogen source with highest activity of $93.38 \mathrm{U} / \mathrm{ml}$ out of all the nitrogen sources screened in this study.Process parameters like $\mathrm{pH}$, temperature, time of incubation, affecting enzyme production were optimized using onefactor-at-a-time approach. Mannanase production was conducted in mineral salt medium and enzyme activity was determined by dinitrosalicylic acid method.The optimal culture conditions obtained from this study helped to standardize the requirements for optimum production of mannanase using agrowastes.
\end{abstract}

Copy Right, IJAR, 2018,. All rights reserved.

\section{Introduction:-}

$\beta$-mannanase is the enzyme that catalyses the endolytic hydrolysis of $\beta-1,4$ mannosidic linkages in mannopolysaccharides such as $\beta-1,4$-mannan, glucomannan and galactomannan. Mannan and heteromannans are a part of the hemicellulose fraction in plant cell walls.(Dhawan, et al. 2008). Mannan endo-1,4- $\beta$-mannosidase or 1,4$\beta$-D-mannanmannohydrolase (EC 3.2.1.78) commonly known as mannanase, randomly hydrolyzes $\boldsymbol{\beta}$-1,4-glycosidic linkage of mannan, glucomannan, galactomannan and galactoglucomannan, to yield manno oligosaccharides (Zhengaqiang Jiang, et al. 2006). Endo - $\beta$-mannanase is an endohydrolase, which is a member of glycosyl hydrolase family 5 and 26. As an endohydrolase it hydrolyses the internal bonds of a polysaccharide. Various mannanases from fungi, yeasts and bacteria as well as from germinating seeds of terrestrial plants has been produced.A vast variety of bacteria, actinomycetes, yeasts and fungi are known to be mannan degraders (Talbot and Sygusch, 1990; Puchartet $a l .$, 2004). Production of B-mannanase by micro-organisms is more promising due to its low cost, high production rate and readily controlled conditions.

In our earlier study Streptomyces sp.AZA12was screened using plate assay technique, and it was observed to give considerable mannanase activity. Based on this information, the isolate was selected for this present study. The objectives of the study are therefore to screen selected agroresidues as substrates for mannanase production as well 
as evaluate the effect of variation of certain process parameters on mannanase production under submerged state fermentation.

\section{Material and method:-} Actinomycetes isolate:

Streptomyces sp. AZA12 isolated from soil sample previously confirmed positive for mannanase activity by plate assay method in our previous work was used in this study. The actinomycete isolate was identified in the Genomebio technology Pvt. Ltd laboratory, Pune, Maharastra. The actinomycete isolate was maintained on guar gum containing agar slants and sub-cultured at regular intervals. They were incubated at $40 \pm 2^{\circ} \mathrm{C}$ for 4 days and stored at $4^{\circ} \mathrm{C}$ in refrigerator.

\section{Chemicals and agroresidues:}

The selected agroresidues were procured from farm fields, local market, and domestic sources. The substrates were washed, sundried, oven dried at $50^{\circ} \mathrm{C}$ and crushed into fine particles and sieved through $1 \mathrm{~mm}$ mesh size. The powdered substrates were stored in plastic container to keep it moisture free for further use.

Guar gum was purchased from HiMedia chemicals and all other chemicals used were of analytical grade.

\section{Media preparation and enzyme production:}

For the production of mannanase in submerged state fermentation, the isolate was grown at $40^{\circ} \mathrm{C}$ in $250 \mathrm{ml}$ Erlenmeyer flask. This medium contained the following ingredients (g/L): guar gum 0.5\%, NaNO3 2, K2HPO4 1, MgSO4.7H2O 0.5, KCl 0.5 and FeSO4.7H2O traces (oladipo o. olaniylet al. 2013). Final pH was adjusted to 7.0 and then sterilized at $121^{\circ} \mathrm{C}$ for 15 minutes. After sterilization, each flask was inoculated with $5 \%$ spore suspension containing $1220 \times 10^{7} \mathrm{cfu} / \mathrm{ml}$. The flasks were incubated at $40^{\circ} \mathrm{C}$ for 4 days at $150 \mathrm{rpm}$. Sterile medium supplemented with guar gum without organism served as the control. After incubation the production medium was filtered to remove the biomass and the clear filtrate was used as crude enzyme for further study.

\section{Enzyme assays:}

Mannanase activity was assayed in the reaction mixture composing of $0.5 \mathrm{ml}$ of $50 \mathrm{mM}$ potassium phosphate buffer $\mathrm{pH} 7.0$ and $1 \%$ Guar Gum (GG) with $0.5 \mathrm{ml}$ of supernatant at $45^{\circ} \mathrm{C}$ for $60 \mathrm{~min}$. Amount of reducing sugar released was determined by the dinitrosalicylic acid reagent (DNS) (Miller, 1959). One unit of mannanase activity was defined as amount of enzyme producing 1 micromole of mannose per minute under the experimental conditions.

\section{Optimization of process parameters:-}

Effect of agroresidues (carbon source) on mannanase production:

Different agrowastes were used as carbon source and evaluated with Guar Gum (GG) serving as control. The broth was distributed into $250 \mathrm{~mL}$ flasks containing $50 \mathrm{ml}$ minimal medium and $1 \%$ of each carbon sources were inoculated with spore suspension of potent strain, the flasks were incubated for 4 days at $40^{\circ} \mathrm{C}$ at $150 \mathrm{rpm}$.

\section{Effect of nitrogen sources on mannanase production:}

The appropriate nitrogen source for mannanase production was determined by supplementing the fermentation medium with different nitrogen sources (organic and inorganic) at $0.2 \%$ level, replacing the prescribed NaNO3 of the fermentation medium. (Oladipo O. Olaniyiet al. 2013).

\section{Effect of $\mathrm{NaCl}$ on mannanase production:}

The effect of $\mathrm{NaCl}$ on mannanase production was studied by supplementing the medium with different $\mathrm{NaCl}$ concentrations ranging from $1 \%$ to $8 \%$. After incubation mannanase assay was carried out according to standard assay procedures (KhamphengPhothichitto, et al. 2006).

\section{Effect of incubation period on mannanase production:}

Fermentation period is an important parameter for enzyme production. In this study, the fermentation experiment was carried out up to 168 hours and production rate was measured at 24 hours intervals. Mannanase assay was carried out according to standard assay procedures (KhamphengPhothichitto, et al. 2006).

\section{Effect of pH on mannanase production:}

The fermentation medium used for mannanase production was initially adjusted using $\mathrm{NaOH}$ or $\mathrm{HCl}$ to cover a $\mathrm{pH}$ range from 3.0 to 9.0 (All adjustments were made before sterilization). After inoculation, the flasks were incubated 
under shaking condition for 4 days at $40^{\circ} \mathrm{C}$. After 4 days of incubation, the culture was centrifuged to obtain supernatants which were used for mannanase assay and protein content determination according to standard assay procedures.

\section{Effect of temperature on mannanase production:}

The effect of different temperatures was studied on mannanase production .After inoculation, the flasks were incubated at different temperatures ranging from $20^{\circ} \mathrm{C}$ to $50^{\circ} \mathrm{C}$. After incubation mannanase assay was carried out according to standard assay procedures (KhamphengPhothichitto, et al. 2006).

\section{Effect of sugars on mannanase production:}

Different sugars were supplemented to evaluate the induction or repression on mannanase production. (Akinyele, et al. 2013). After incubation mannanase assay was carried out according to standard assay procedures (KhamphengPhothichitto, et al. 2006).

\section{Results and discussion:-}

Effect of carbon source (agroresidues) on mannanase activity:

Agro-industrial by-products are available in large amounts and they have been used for the production of several enzymes (Mabrouk and El Ahwany, 2008; Howard et al., 2003). Table 1 shows that several types of agro-wastes were evaluated as substrates for mannanase production by Streptomyces sp.AZA12 in comparison to guar gum (control). Mannanase synthesis by Streptomyces sp.AZA12 was highest when soystraw was utilized as a carbon source compared to other agro-wastes $(56.46 \mathrm{U} / \mathrm{ml})$. However, the value obtained for soystraw was significantly lower than that of guar gum (control) $(76.69 \mathrm{U} / \mathrm{ml})$. It might be due to the fact that soyastraw provided adequate amount of nutrients like proteins, carbohydrates, fats, fibers, ash, calcium, magnesium, phosphorous, potassium, sulphur, amino acids etc. (Akinyele, et al. 2013).

\section{Fig 1.0}

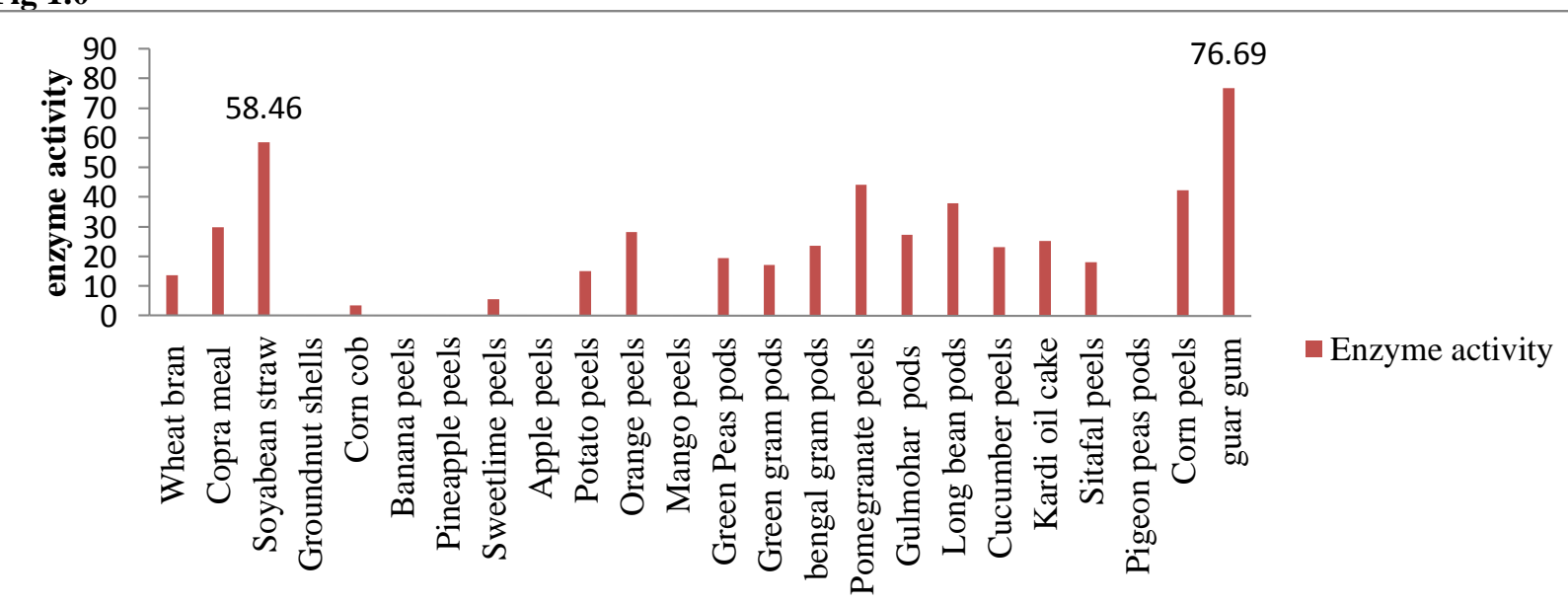

Agrowastes

Effect of different nitrogen sources on mannanase activity:-

In this present work, different nitrogen sources were added separately to the fermentation medium at $0.2 \%$ replacing NaNO3 (control) in the mineral salt medium .Among the tested nitrogen sources; aspargine gave maximum enzyme activity $93.38 \mathrm{U} / \mathrm{ml}$. Okeke and Obi (1993) reported the more enzyme production using inorganic nitrogen sources as compared to the organic nitrogen sources from Arthrographissp. They mentioned that the use of the organic nitrogen sources could also be advantageous than the inorganic ones, as the organic sources are cheaper in cost and also not involved in the competition with active site of the enzyme. 
Fig:2.0

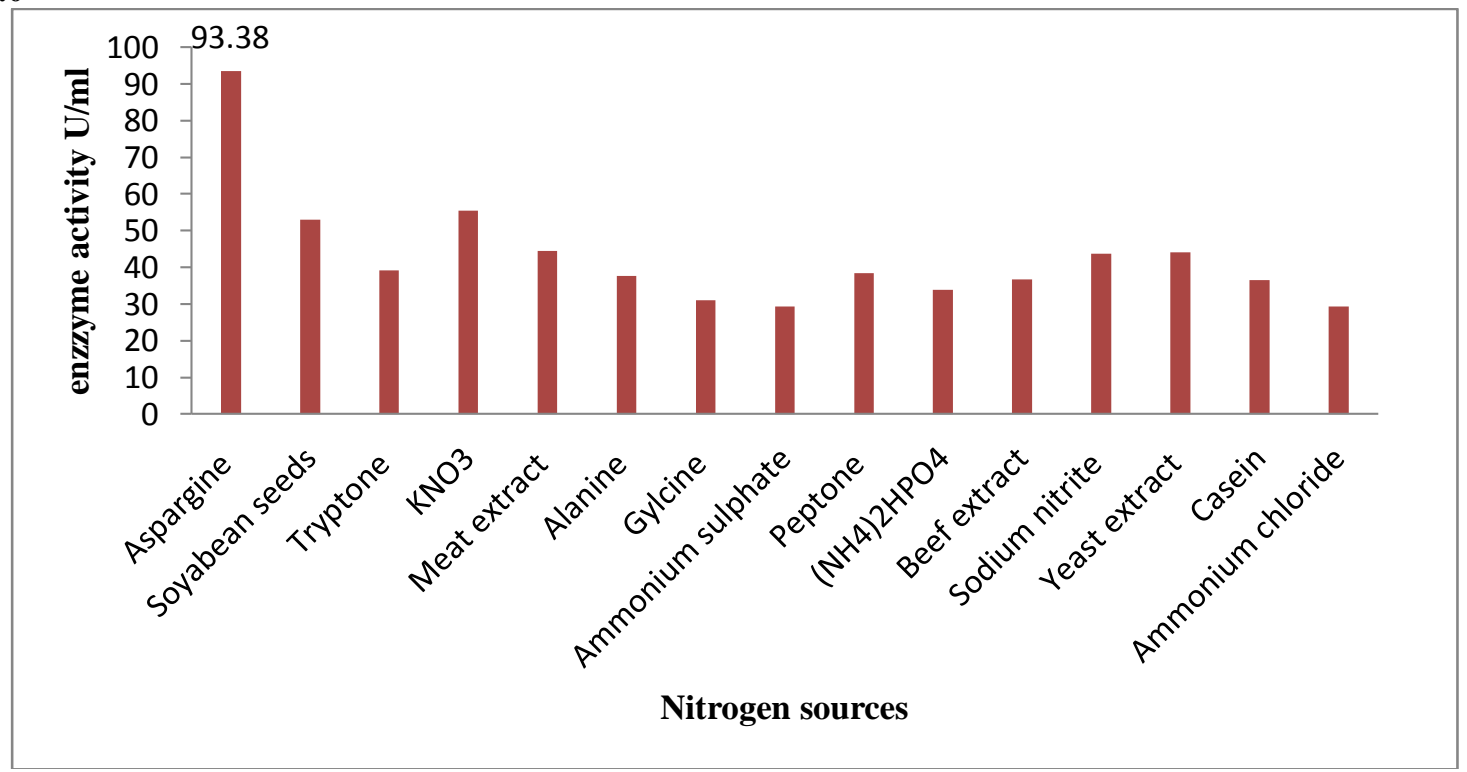

\section{Effect ot $\mathrm{NaCl}$ concentration:}

The Streptomyces sp.AZA12 was able to grow at $8 \%$ of $\mathrm{NaCl}$ concentration but the mannanse activity decreased as the concentration of $\mathrm{NaCl}$ increased. After $3 \%$ of $\mathrm{NaCl}$ concentration there was drastic decrease in mannanase activity and there was no enzyme activity at $8 \% \mathrm{NaCl}$.

Fig 3.0

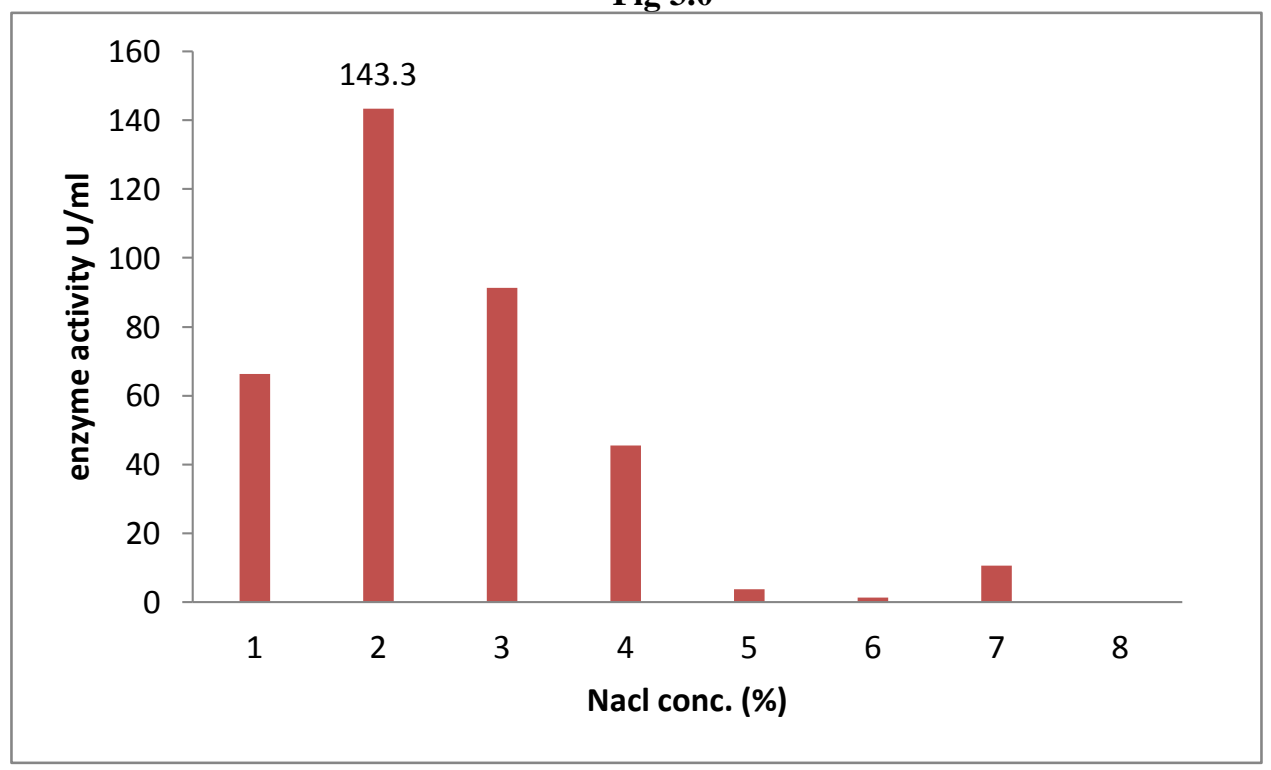

Effect of incubation period:-

Data presented in Figure 4 showed the effect of different incubation periods on mannanase production by Streptomyces sp. AZA12. From the results, it was found that mannanase revealed its best production at 72 hrs of incubation $(90.18 \mathrm{U} / \mathrm{ml})$. At longer incubation periods beyond $72 \mathrm{hrs}$, the activity decreased. The decrease in the production of mannanase by Streptomyces sp. AZA12 after $72 \mathrm{hrs}$ of incubation period might be due to the depletion of nutrients and accumulation of other by-products in the fermentation medium initiating autolysis of cells (Meenakshiet al., 2010; Malik et al., 2010). The result obtained was same as the findings of other works that recorded maximum mannanase production at $72 \mathrm{hrs}$ for Penicilliumocittanis(Blibechet al., 2010). 
Fig 4.0

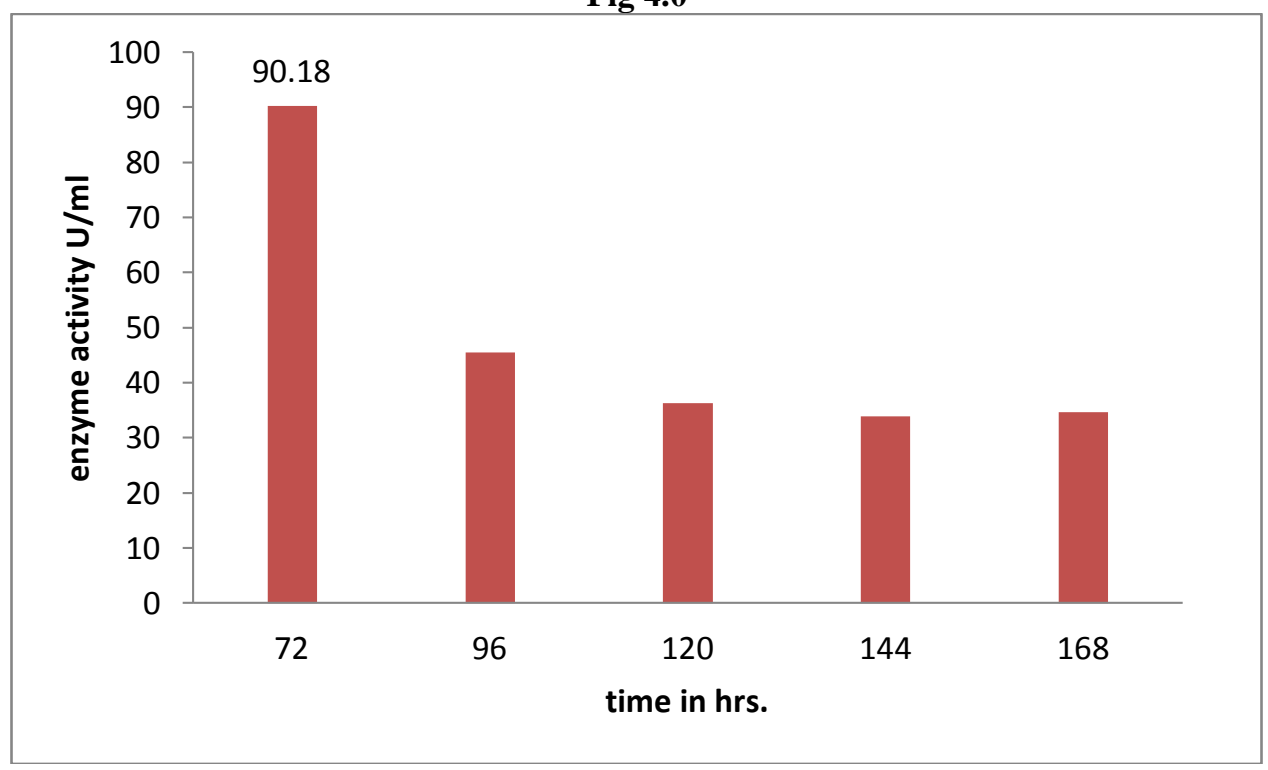

Effect of pH on mannanase production:

The effect of $\mathrm{pH}$ on mannanase production is shown in fig 5 . The best mannanase production was seen at $\mathrm{pH} 7$ with mannanase activity of $74.31 \mathrm{U} / \mathrm{ml}$. At $\mathrm{pH} 8$ there was drastic decrease in mannanase activity. The increase in mannanase activity at $7 \mathrm{pH}$ might be due to the fact that acidic proteases that are active in degrading mannase protein are in active (. Corresponding to the $\mathrm{pH}$ optimum of both bacterial and fungal mannanase, they were in the range of 3.0-6.0 (Sachslehner A., et al. 1999). However, some of mannanases from Bacillus subtilisKU-1, Bacillus sp. KK01, Bacillus sp. strain JAMB-750, Thermotoganeapolitana5068 and Streptomycesipomoea showed higher optimum $\mathrm{pH}$ in the range of 7.0-10.0 (Takeda N., et al. 2004).

Fig 5.0

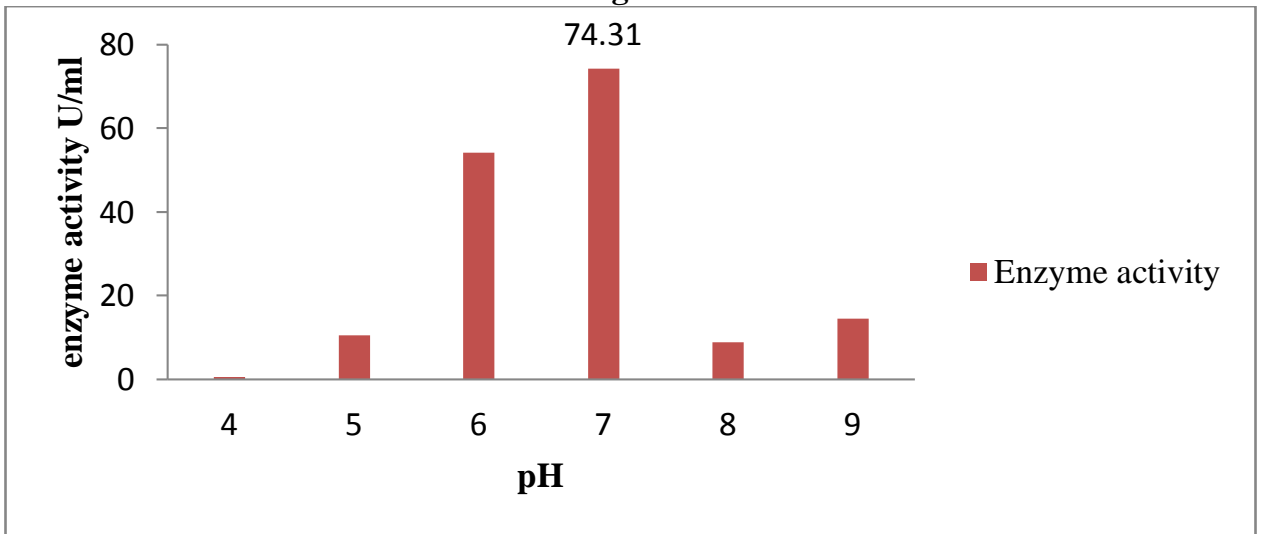

\section{Effect of temperature on mannanase production:}

The optimum temperature for the production of mannanase from Streptomyces AZA12 was investigated from $20^{\circ} \mathrm{C}$ to $45^{\circ} \mathrm{C}$. The medium was inoculated and incubated at different temperature viz. $20^{\circ} \mathrm{C}, 25^{\circ} \mathrm{C}, 30^{\circ} \mathrm{C}, 35^{\circ} \mathrm{C}, 40^{\circ} \mathrm{C}$ and $45^{\circ} \mathrm{C}$. Since the organism is a mesophile, very less growth as well as low amount of mannanase production was observed at higher temperature of $45^{\circ} \mathrm{C}$. Maximum enzyme production was observed at $30^{\circ} \mathrm{C}$ (Fig. 6). 
Fig. 6.0

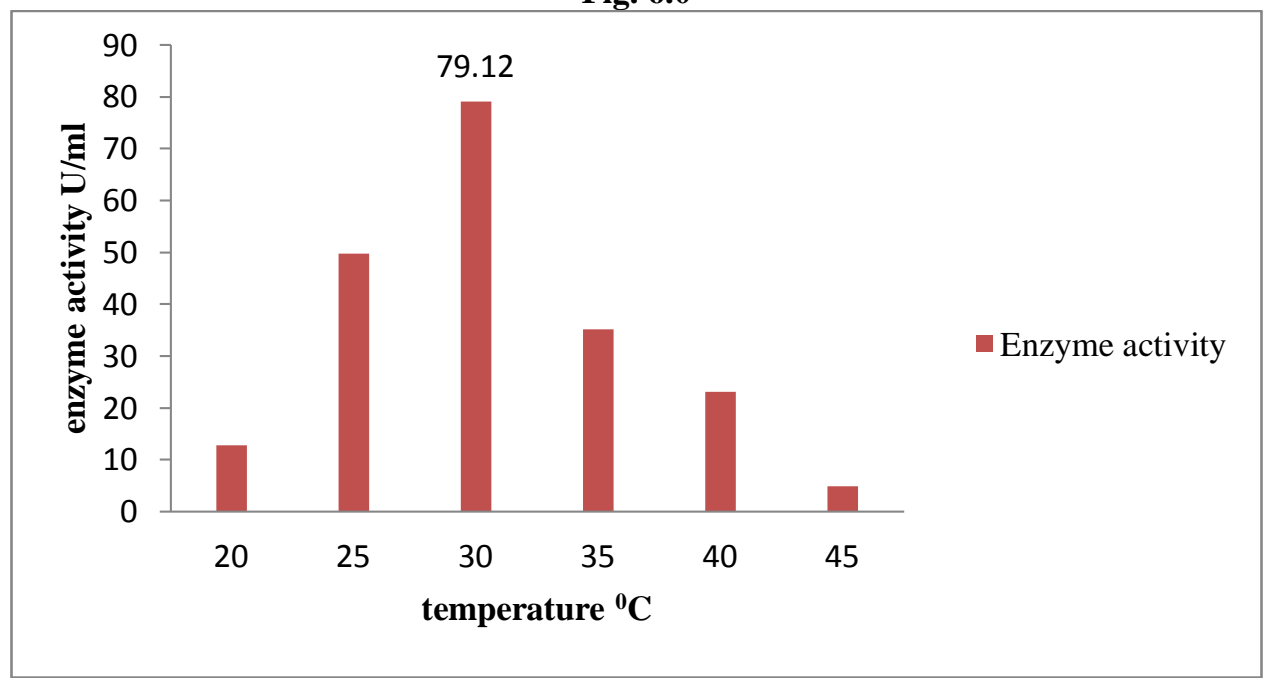

Effect of sugars on mannanase production:

The effect of various sugars The effect of various sugars $(0.2 \mathrm{~g} / \mathrm{l})$ (Akineyele, et al. 2013) supplemented to the enzyme production medium containing guar gum in order to evaluate its induction or repression effect on mannanase production were tested (fig 7). The highest activity was exhibited by guar gum (control). Addition of different sugars with guar gum was accompanied by severe inhibitory effects on enzyme production. Such results may be due to the catabolic repression processes when easily assimilated carbon sources were added (Moussa and Thawat, 2007; Mabrouk and El-Ahwany, 2008).

Fig.7.0

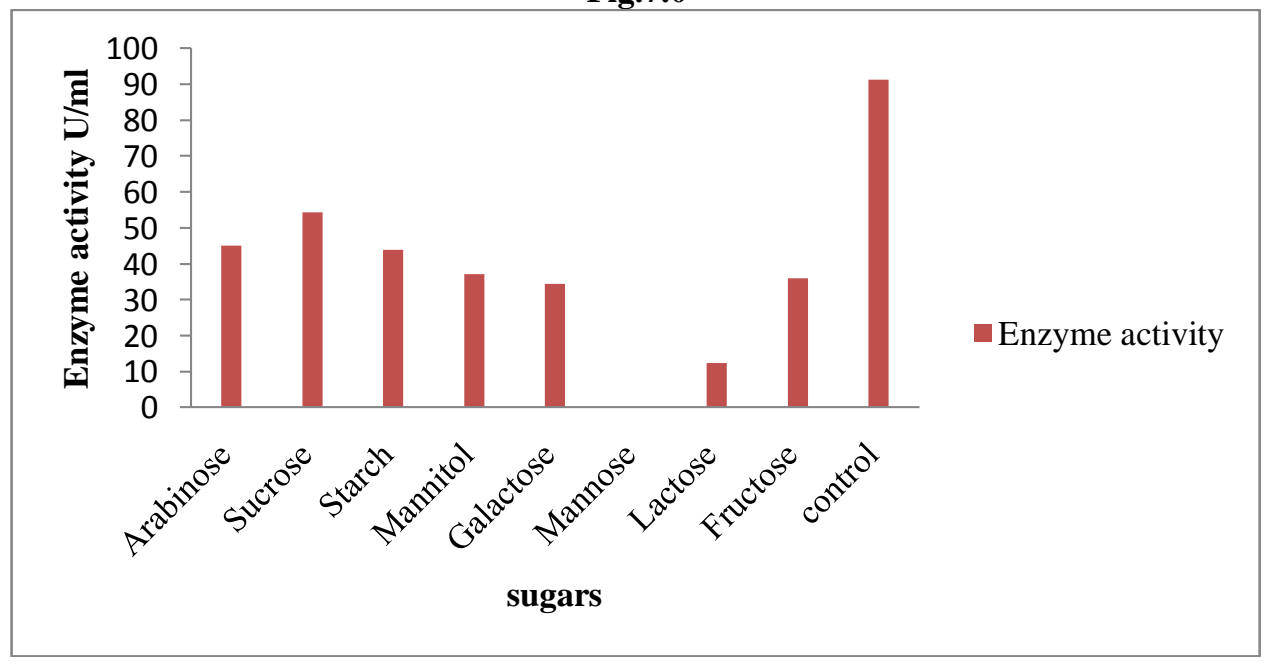

\section{Conclusion:-}

According to results Streptomyces AZA12 has potential to be an indigenous source of mannanase production using cheap agrowaste soystraw as sole source of carbon in submerged fermentation. The optimal process parameters for the production of mannanase were screened of which aspargine as nitrogen source, $72 \mathrm{hrs}$ of incubation period, $\mathrm{pH} 7$, $30^{\circ} \mathrm{C}$ temperature, was found to be the best for mannanase production. There was no induction in mannanase production after sugar supplementation to the production medium. Soystraw are agrowastes that could have good biotechnological potential.

\section{Acknowledgement:-}

The research was funded by UGC under Rajiv Gandhi National fellowship. The authors are also thankful to Government Institute of Science, Department of Microbiology, Aurangabad for its support. 


\section{References:-}

1. Ali, M.N. (2011). Production of bioethanol fuel from renewable agro based cellulosic wastes and waste news papers. Intl. J. of Engg. Sci. and Technol. (IJEST): 884-893.

2. Akinyele, J.B., Olaniyii, O.O., Adetunji, C.O. 2013. Screening and optimization of nutritional conditions for mannanase production by PenicilliumitalicumLAD-A5 in solid state cultivation. E3 Journal of Biotechnology and Pharmaceutical Research, 4(2), 35-41.

3. Blibech M, EllouzGhorbel MR, Fakhfakh I (2010). Purification and characterisation of a low molecular weight of $\beta$ - mannanase from PenicelliumoccitanisPol6. Appl. Biochem. Biotechnol., 160:1227-1240.

4. Cerveró, J.M., Skovgaard, P.A., Felby, C., Sørensen, H.R. and Jørgensen, H. (2009). Enzymatic hydrolysis and fermentation of palm kernel press cake for production of bioethanol. Enzyme and Microbial Technol. 46: 177184.

5. Dhawan S., Kaur J., (2007). Microbial mannanases: an overview of production and applications.Crit Rev Biotechnol. 2007 Oct-Dec;27(4):197-216.

6. Girio, F.M., Fonseca, C., Carvalheiro, F., Duarte, L .C, Marques, S. and Bogel-Lukasik, R.(2010). Hemicelluloses for fuel ethanol: A review. Bio resource Technol. 13:4775-4800.

7. Jiang, Z., et al. (2006). High-level production, purification and characterization of a thermostable b-mannanase from the newly isolated Bacillus subtilis WY34. Carbohydrate Polymers 66: 88-96.

8. Juhasz, T., Szengyel, Z., Reczey, K., Siika-Aho, M., and Viikari, L. (2005). Characterization of cellulases and hemicellulases produced by Trichodermareesei on various carbon sources. Process Biochem. 40:3519-3525.

9. Khampheng, P., Sunee, N. and Suttipun, K. (2006). Isolation, screening and identification of mannanase producing microorganisms. Kasetsart Journal (National Science) 40:26 - 38.

10. Khanongnuch, C., Asada, K., Tsuruga, H., Toshihiko, Kinoshita, S., and Lumyong, S. (1998). ßMannanase and xylanase of Bacillus subtilis $5 \mathrm{H}$ active for bleaching of crude pulp. J. Ferment. Boeing. 5:461-466.

11. KhairulAsfamawi K., Noraini S., Darah I., et al. (2013). Isolation, screening and identification of mannanase producer Microorganisms J. Trop. Agric. and Fd. Sc. 41(1)(2013): 169-177.

12. Lin, S. S., Dou, W. F., Xu, H., Li, H. Z., Xu, Z. H., Ma, Y. 2007. Optimization of medium composition for the production of alkaline -mannanase by alkaliphilicBacillus sp. N16-5 using response surface methodology. Applied Microbiology and Biotechnology, 75 (5): 10151022.

13. Lee, J.T, Connor-Appleton, S., Bailey, C.A., and Cartwright, A.L. (2005). Effects of Guar Meal By-Product with and without B-MannanaseHemicell on Broiler Performance, Poultry Science 84:1261-1267.

14. Lowry OH, Rosebrough N.J, Farr AL, Randall RJ (1951). Protein measurement with the folin phenol reagent. J. Biol. Chem. 193: 265-275.

15. Mabrouk, M.E.M and El Ahwany, A.M.D. (2008). Production of $\beta$-mannanase by Bacillus amylolequifaciens 10A1 cultured on potato peels, African J. of Biotechnol. Vol. (7) 8:1123-1128.

16. Martin, D.A., et al. (2011). Agro industrial Wastes as Substrates for Microbial Enzymes Production and Source of Sugar for Bioethanol Production, Integrated Waste Management - Volume II, Mr. Sunil Kumar (Ed.), ISBN: 978-953-307-447-4.

17. Manjula, S., Shinde, M., Lalitha, J. 2010. Optimization of culture conditions for the production of -mannanse from an agar utilizing Paenibacillussp..MSL-9 TheBioscan, 5(1): 75-79.

18. Meenakshi, Singh, G., Bhalla, A., Hoondal, G.S. 2010. Solid state fermentation and characterization of partially purified thermostablemannanase from Bacillus sp. MG-33. Bioresources, 5:1689-1701.

19. Meenakshi, Singh, G., and Hoondal, G.S. (2011).Bioleaching of wheat straw rich soda pulp by the application of thermophilic mannanase from Bacillus sp. MG-33, Intl. J.of Environ. Sci., vol. (2).

20. Menon, V. and Rao, M. (2012). Trends in bioconversion of lignocellulose: Bio fuels, platform chemicals \&biorefinery concept. Progress in Energy and Combustion Sci. 38:522-550.

21. Miller G.L. (1959). Use of Dinitrosalicylic acid reagent for determination of reducing sugars. Anal. Chem. 31: 426-428.

22. Moussa TAA, Tharwat NA (2007). Optimization of cellulase and $\beta$-glucosidase induction by sugarbeet pathogen Sclerotiumrolfsii. Afr. J. Biotechnol., 6: 1048-1054.

23. Mohammad, Z., Abe, U., and Hizukuri, S.(1996). Multiple forms of $\beta$-mannanase from Bacillus sp. KKOl.Enzyme and Microbial Technol. 18:95-98.

24. Olaniyi, O.O., Igbe, F.O., Ekundayo, T.C., (2013). Optimization studies on mannanase production by Trichosporonoidesoedocephalisin submerged state fermentation. Journal of Biotechnology and Pharmaceutical Research, 4(7): 110-116.

25. Okeke BC, Obi CKS (1993). Production of cellulolytic and xylanolytic enzymes by an Arthrographisspecies. World J. Microbiol. Biotechnol., 9: 345-349. 
26. Petkowicz, C.L.O., Reicher, F., Chanzy, H. Taravel, F.R.,andVuong, R.(2001). Linear mannan in the endosperm of Schizolobiumamazonicum. Carbohydrate Polymers 44:107-112.

27. Puchart V, Vršanská M, Svoboda P, Pohl J, Ögel ZB, Biely P (2004). Purification and characterisation of two forms of endo- $\beta-1,4$-mannanase from a thermotolerant fungus, Aspergillus fumigates IMI 385708 (formerly Thermomyceslanuginosus IMI 158749). Biochim. Biophys. Acta.1674(3): 239-250.

28. Sachslehner A, Haltrich D. Purification and some properties of a thermostable acidic endo- $\beta$-1,4-D-mannanase from Sclerotium(Athelia) rolfsii. FEMS Microbiol. Lett. 1999;177:47-55.

29. Sweeney, M.D. and Xu, F. (2012). Biomass Converting Enzymes as Industrial Biocatalysts for Fuels and Chemicals: Recent Developments, Catalysts2:244-263.

30. Talbot G., SyguschJ.,.Purification and characterization of thermostable beta-mannanase and alpha-galactosidase from Bacillus stearothermophilus.Appl Environ Microbiol. 1990 Nov;56(11):3505-10.

31. Tse-Chun Lin, Chinshuh Chen (2004). Enhanced mannanase production by submerged culture of AspergillusnigerNCH-189 using defatted copra based media. Process Biochemistry 39:1103-1109.

32. Takeda, N., et al. (2004). Purification and enzymatic properties of a highly alkaline mannanase from alkaliphilicBacillus sp. strain JAMB-750 J. Biol. Macromol., (4) 2: 67-74.

33. Zyl, W.H, Rose, S.H., Trollope, K., and Görgens, J.F. (2010). Fungal $\beta$-mannanases: Mannan hydrolysis, heterologous production and biotechnological applications, Review. Process Biochem. (45):1203-1213. 